\title{
Karakteristik Nugget Ikan Tuna (Thunnus sp.) dengan Penambahan Ubi Ungu
} (Ipomoea batatas)

\section{The characteristics of Tuna (Thunnus sp.) nugget with filled by Purple Sweet Potato (Ipomoea batatas)}

\author{
Raja Bonan Dolok Sormin*, Febe Gasperz, Syanne Woriwun \\ Jurusan Teknologi Hasil Perikanan, Fakultas Perikanan dan Ilmu Kelautan, Universitas Pattimura \\ Jl. Mr. Chr. Soplanit, Kampus Poka, Ambon 97233
}

*Penulis korespondensi: Raja B.D. Sormin, e-mail: sormindolok@gmail.com

Tanggal submisi: 10 Januari 2020; Tanggal penerimaan: 1 April 2020

\begin{abstract}
This study was aimed to study the characteristics of tuna (Thunnus sp.) chunks nugget supplemented with purple sweet potato as filler both subjectively and objectively. A three-treatment experiment with five replications was applied in this research. Parameters tested included sensory test (aroma, taste, and texture), proximate analysis (moisture, ash, protein, fat, and carbohydrate contents). The treatment of purple sweet potato as filler on tuna fish nugget was found to influence the quality of the nugget. The result of the sensory test showed that treatment of 10\%:90\% purple sweet potato to tuna chunks had the highest score on aroma, taste, and texture than 20\%:80\% and 30\%:70\%. This was due to the higher proportion of tuna chunks resulted in distinctive nuggets aroma, tasty, and firm texture when it was bitten. The results of the proximate analysis showed that the addition of purple sweet potato on tuna nuggets had a very significant effect on protein, fat, and ash contents. The higher the percentage of purple sweet potato added to tuna nugget, the smaller the protein content and the ash content. However, the addition of purple sweet potato did not affect the moisture content of tuna nuggets. Overall, the proximate content of tuna nuggets in this study was found to meet the standard recommended by SNI for fish nuggets.
\end{abstract}

Keywords: characteristics, nugget, sensory, proximate, purple sweet potato

\begin{abstract}
ABSTRAK
Penelitian ini bertujuan untuk mempelajari karakteristik nugget tetelan ikan tuna (Thunnus sp.) dengan penambahan ubi ungu baik secara subjektif maupun objektif. Metode penelitian adalah eksperimen dengan tiga perlakuan dan lima kali ulangan. Parameter uji terdiri dari: uji organoleptik (aroma, rasa, dan tekstur), uji proksimat (kadar air, kadar abu, kadar protein, kadar lemak dan kadar karbohidrat). Perlakuan penambahan ubi ungu pada nugget tetelan ikan tuna mengakibatkan perbedaan mutu pada nugget yang dihasilkan. Hasil organoleptik menunjukkan bahwa perlakuan perbandingan konsentrasi ubi ungu:tetelan ikan tuna 10\%:90\%, memiliki aroma, rasa dan tekstur yang lebih tinggi dibandingkan dengan perlakuan perlakuan perbandingan konsentrasi ubi ungu:tetelan ikan tuna 20\%:80\% dan 30\%:70\%. Panelis lebih menyukai perlakuan perbandingan konsentrasi ubi ungu:tetelan ikan tuna 10\%:90\%, hal ini disebabkan oleh penggunaan tetelan ikan membuat nugget beraroma khas, rasanya gurih serta teksturnya tidak hancur ketika digigit. Hasil uji proksimat menunjukkan bahwa penambahan ubi ungu pada pembuatan nugget ikan tuna berpengaruh sangat nyata terhadap kadar protein, kadar lemak dan kadar abu. Persentasi ubi ungu pada nugget ikan tuna semakin besar maka kadar protein, kadar abu semakin kecil, namun penambahan ubi ungu tidak berpengaruh terhadap kadar air nugget tuna. Nilai proksimat nugget ikan tuna secara keseluruhan dari hasil penelitian ini berada pada standar yang di anjurkan oleh SNI nugget ikan.
\end{abstract}

Kata kunci: karakteristik, nugget, organoleptik, proksimat, ubi ungu 


\section{PENDAHULUAN}

Tetelan ikan tuna adalah limbah hasil pengolahan tuna loin, yang terdiri dari jenis daging merah dan sebagian daging ikan putih. Tetelan juga merupakan daging ikan tuna yang menempel pada tulang atau daging ikan yang tidak dapat di manfaatkan karena sayatannya yang tidak merata. Kantun et al. (2014) menyatakan, dari satu ekor ikan tuna yang diolah menjadi loin akan menghasilkan loin sebesar $39,7 \%$ dan limbah sebesar $60,3 \%$ terdiri dari: sekitar $23,1 \%$ tetelan, kepala $17,8 \%$, tulang dan sirip $8,5 \%$, jantung $0,6 \%$, jeroan $3,2 \%$ serta darah dan kulit $4,6 \%$. Kelemahan tetelan ikan tuna adalah berbau amis, sehingga kurang disukai konsumen, untuk mengurangi kelemahan ini dilakukan diversifikasi pengolahan. Perlakuan pengukusan, dan penambahan bumbu-bumbu dapat mengurangi bau amis tetelan ikan tuna ini. Tetelan ikan tuna berpotensi digunakan dalam produk diversifikasi hasil olahan perikanan seperti nugget, bakso otakotak, kerupuk, surimi, dan lain-lain.

Nugget merupakan produk olahan berbentuk cetakan dan potongan, berbahan dasar daging lumat berlapis tepung berbumbu (Maghfiroh, 2000). Nugget relatif mempunyai masa simpan yang lama apabila didinginkan atau dibekukan. Nugget ikan mempunyai keunggulan yaitu makanan yang menyehatkan, mempunyai nilai gizi, tekstur yang empuk, variasi rasa dan penampilan, dapat dikonsumsumsi oleh hampir semua tingkatan umur dan dapat dipasarkan baik di pasar tradisional maupun pasar modern. Dalam memperbaiki tekstur dan nilai gizi nugget dilakukan penambahan pengisi (filler) dari berbagai bahan berserat seperti tepung kanji atau tapioka, tepung umbi-umbian, jamur, kacang hijau, ubi singkong, rumput laut dan sagu (Desmelati dan Hayati, 2008; Kusumaningrum et al., 2013; Laksono et al., 2012; Nurhalimah et al., 2012; Restu, 2012; Rosyidi et al., 2008; Saniah dan Rahani, 2011; Yusop et al., 2009). Priwindo (2009), menyatakan dalam pembuatan adonan nugget, karbohidrat sangat diperlukan sebagai pengikat bahan yang satu dengan yang lain sehingga dihasilkan tekstur yang baik. Karbohidrat sebagai bahan pengikat berasal dari tepung bijibijian dan umbi-umbian seperti tepung terigu, tepung beras, tepung maizena, dan tepung tapioka.

Ubi jalar sebagai bahan pengisi (filler) mengandung karbohidrat sekitar $27,9 \%$ pada keadaan berkadar air $68,5 \%$, namun pada bentuk tepung ubi jalar kandungan karbohidratnya dapat mencapai 85,26\% dengan kadar air 7\% (Depkes, 1981). Zuraida dan Supriati (2001) menyatakan bahwa selain kandungan karbohidrat yang tinggi, tepung ubi jalar juga mengandung kadar abu dan kadar serat yang tinggi. Kandungan karbohidrat dan kalori dari tepung ubi jalar hampir setara dengan tepung terigu. Hal ini menjadi pertimbangan dalam pemanfaatan tepung ubi jalar sebagai bahan pensubstitusi terigu sebagai bahan yang menyehatkan.

Penelitian ini bertujuan mempelajari karakteristik produk nugget tetelan ikan tuna (Thunnus sp.) dengan penambahan ubi ungu (Ipomoea batatas) baik secara subjektif maupun objektif.

\section{METODE PENELITIAN}

\section{Bahan}

Bahan utama terdiri atas tetelan ikan tuna (Thunnus sp.) dan ubi ungu. Tetelan ikan tuna didapatkan dari PT. Harta Samudra Tantui Ambon, kemudian dibawa ke Laboratorium Teknologi Hasil Perikanan Fakultas Perikanan dan Ilmu Kelautan, Universitas Pattimura Ambon. Ubi ungu didapatkan dari Pasar Transit Passo. Bahan-bahan kimia yang digunakan untuk proses preparasi dan analisa sampel adalah pure analysis.

\section{Metode Penelitian}

Metode penelitian adalah eksperimen dengan tiga taraf perlakuan yaitu perbandingan konsentrasi ubi ungu dan tetelan ikan tuna, meliputi ubi ungu 10\%:tetelan ikan tuna 90\%, ubi ungu $20 \%$ : tetelan ikan tuna $80 \%$, dan ubi ungu $30 \%$ :tetelan ikan tuna $70 \%$. Semua perlakuan diulang sebanyak lima kali ulangan. Parameter uji terdiri dari: uji organoleptik (aroma, rasa, dan tekstur), uji proksimat (air, abu, protein, lemak dan karbohidrat).

\section{Prosedur Penelitian}

\section{Pembuatan Nugget Ubi Ungu (Herawati, 2009)}

Tetelan ikan tuna yang digunakan dalam pembuatan nugget mengikuti formulasi seperti ditunjukkan pada Tabel 1. Prosesnya adalah sebagai berikut: pemisahan serat dari tetelan ikan tuna dan penggilingan daging tuna. Kemudian ditimbang tetelan ikan sebesar $450 \mathrm{~g}, 400 \mathrm{~g}, 350 \mathrm{~g}$, tepung terigu sebanyak $100 \mathrm{~g}$, telur yang digunakan sebanyak 3 butir (1 butir untuk adonan, 
dan 2 butir untuk pemaniran), ubi ungu ditimbang masing-masing $50 \mathrm{~g}, 100 \mathrm{~g}$ dan $150 \mathrm{~g}$, serta bumbu-bumbu seperti bawang putih sebanyak 25 $\mathrm{g}$, bawang Bombay sebanyak $40 \mathrm{~g}$ dan merica $5 \mathrm{~g}$. Seterusnya ikan tuna lumat dicampurkan menjadi adonan dan kemudian dicetak sesuai dengan bentuk yang diinginkan. Setelah itu dikukus selama waktu 15-20 menit. Setelah dikukus, diangkat lalu nugget dibiarkan dingin selama 30 menit kemudian di potong panjang $2 \mathrm{~cm}$, dan lebar $5 \mathrm{~cm}$. Nugget kemudian dicelup kedalam telur yang sudah di kocok dan dibaluri tepung panir, selanjutnya untuk tahap I nugget digoreng untuk menentukan yang terbaik (uji organoleptik) dengan 15 orang panelis, kemudian pada tahap II dilanjutkan dengan uji proksimat (air, abu, protein, lemak, dan karbohidrat).

\section{Uji Organoleptik}

Pengujian organoleptik yang digunakan adalah uji kesukaan yang menyangkut penilaian seseorang mengenai sifat atau kualitas suatu bahan yang menyebabkan orang menyenangi (Soekarto, 1990). Pada pengujian ini panelis mengemukakan tanggapan pribadi, yaitu kesan yang berhubungan dengan kesukaan atau tanggapan senang tidaknya terhadap kualitas yang dinilai berdasarkan skala kesukaan yang disediakan.

Uji Organoleptik merupakan hasil pengujian nilai kesukaan terhadap aroma, rasa, dan tekstur. Panelis semi terlatih berjumlah 15 orang. Spesifikasi nilai organoleptik adalah sebagai berikut: amat sangat suka 9; sangat suka 8; suka 7; agak suka 6; netral 5; agak tidak suka 4; tidak suka 3 ; sangat tidak suka 2 ; amat sangat tidak suka 1 (BSN, 2006).

\section{Analisa Kadar Air (AOAC, 2005)}

Metode yang digunakan dalam menentukan kandungan air adalah metode termogravimetri. Metode ini dilakukan dengan cara menguapan molekul air bebas dalam contoh bahan selanjutnya menimbang contoh hingga beratnya konstan. Banyaknya air yang diuapkan dapat dihitung dari selisih berat contoh sebelum pengeringan dan berat contoh setelah dikeringkan.

Prosedur uji kadar air sebagai berikut: cawan timbang di panaskan dalam oven (Memmert, Germany) selama 30 menit pada suhu $100-105^{\circ} \mathrm{C}$, selanjutnya cawan yang sudah kering didinginkan dalam desikator sekitar 15 menit dan ditimbang memakai timbangan analitik (Ohaus, USA). Sebanyak 2 g contoh dimasukkan ke dalam cawan timbang yang sudah kering, selanjutnya cawan dan contoh dikeringkan dalam oven pada suhu $100-105^{\circ} \mathrm{C}$ selama 6 jam. Cawan pengering dan contoh diamati setelah 6 jam pengeringan dengan cara mendinginkannya dalam desikator selama 30 menit dan ditimbang.

\section{Analisa Kadar Abu (AOAC, 2005)}

Kandungan abu dalam contoh adalah merupakan sisa mineral hasil pembakaran bahan organik pada contoh. Prosedur analisa adalah sebagai berikut: mengeringkan cawan porselin di dalam oven (Memmert, Germany) pada suhu $105^{\circ} \mathrm{C}$ selama 1 jam, kemudian didinginkan selama 30 menit dalam desikator dan kemudian ditimbang beratnya. Bahan contoh sebanyak 2 g kemudian dimasukkan ke dalam cawan porselin yang sudah kering dan dipijarkan di atas nyala api pembakar bunsen hingga tidak berasap lagi. Setelah itu, masukkan kedalam tanur listrik (Barnstead Thermoline-1400 Furnace, USA) dengan suhu $650^{\circ} \mathrm{C}$ selama \pm 12 jam. Selanjutnya cawan didinginkan selam 30 menit di dalam desikator, kemudian ditimbang hingga didapat berat tetap.

\section{Analisis Kadar Lemak (AOAC, 2005)}

Kandungan lemak nugget tuna dianalisa menggunakan metode Soxhlet. Lemak dalam contoh nugget diekstrak menggunakan bahan pelarut non polar yaitu petroleum ether (Merck, Germany). Prosedur analisis kadar lemak adalah seperti berikut: Labu lemak pertama sekali dikeringkan di dalam oven (Memmert, Germany) selama 30 menit pada suhu $100-105^{\circ} \mathrm{C}$, setelah itu labu didinginkan dalam desikator selama 15 menit dan ditimbang dinyatakan sebagai A. Contoh sebanyak kurang lebih $2 \mathrm{~g}$ dinyatakan sebagai B ditimbang dan dibungkus dengan kapas bebas lemak dan kemudian dibungkus lagi menggunakan kertas saring, kemudian dimasukkan ke dalam labu ekstraksi ekstraksi Soxhlet yang telah dihubungkan dengan labu lemak. Petroleum eter dituangkan dalam tabung ekstraksi hingga contoh terendam. Ekstraksi lemak dilakukan selama 5-6 jam atau sampai warna pelarut lemak dalam tabung soxhlet berwarna jernih. Tahapan selanjutnya adalah memisahkan pelarut dari lemaknya dengan cara penyulingan, ekstrak lemak yang ada dalam labu lemak selanjutnya dikeringkan dalam oven bersuhu $100-105^{\circ} \mathrm{C}$ sekitar 1 jam atau sampai pelarut teruapkan semua, kemudian labu lemak didinginkan dalam desikator dan ditimbang dinyatakan dengan $\mathrm{C}$. Tahap pengeringan labu lemak diulangi sehingga diperoleh berat yang konstan. Kadar lemak dihitung dengan rumus: 
Tabel 1. Formulasi nugget ikan tuna

\begin{tabular}{lccc}
\hline \multirow{1}{*}{ Bahan } & \multicolumn{3}{c}{ Jumlah } \\
\cline { 2 - 4 } & $\mathbf{1 0 \%} \mathbf{~ 9 0 \%}$ & $\mathbf{2 0 \%} \mathbf{8 0 \%}$ & $\mathbf{3 0 \%} \mathbf{: 7 0 \%}$ \\
\hline Tetelan ikan tuna & $450 \mathrm{~g}$ & $400 \mathrm{~g}$ & $350 \mathrm{~g}$ \\
Ubi ungu & $50 \mathrm{~g}$ & $100 \mathrm{~g}$ & $140 \mathrm{~g}$ \\
Tepung terigu & $100 \mathrm{~g}$ & $100 \mathrm{~g}$ & $100 \mathrm{~g}$ \\
Bawang bombay & $40 \mathrm{~g}$ & $40 \mathrm{~g}$ & $40 \mathrm{~g}$ \\
Telur & $3 \mathrm{butir}$ & $3 \mathrm{butir}$ & $3 \mathrm{butir}$ \\
Bawang putih & $25 \mathrm{~g}$ & $25 \mathrm{~g}$ & $25 \mathrm{~g}$ \\
Merica & $5 \mathrm{~g}$ & $5 \mathrm{~g}$ & $5 \mathrm{~g}$ \\
\hline
\end{tabular}

Lemak total $(\%)=\frac{C-A}{B} \times 100 \%$

Keterangan: $\mathrm{A}=$ berat labu alas bulat kosong (g); $\mathrm{B}=$ berat sampel $(\mathrm{g}) ; \mathrm{C}=$ berat labu alas bulat dan lemak hasil ekstraksi $(\mathrm{g})$

\section{Analisis Kadar Protein (AOAC, 2005)}

Prosedur analaisis kandungan protein terdiri dari tiga tahapan. Tahap pertama adalah destruksi, tahapan ini dimulai dengan menimbang sekitar 0,1$0,5 \mathrm{~g}$, kemudian ditempatkan pada labu kjeldahl berukuran $100 \mathrm{~mL}$, selanjutnya ditambahkan seperempat bagian tablet kjeltab dan laurtan $\mathrm{H}_{2} \mathrm{SO}_{4}$ (Merck, Germany), kemudian didekstruksi menggunakan Kjeldigester (Buchi, Netherlands) sampai larutan menjadi hijau jernih. Tahapan selanjutnya adalah destilasi menggunakan menggunakan Distillation Unit (Buchi, Netherlands). Prosedur destilasi adalah sebagai berikut: Larutan hasil destruksi dibiarkan dingin dan diencerkan dengan aquades sampai tanda tera, kemudian disetting pada alat destilasi, ditambahkan dengan 5-10 mL NaOH 30-33\% dan dilakukan destilasi. Destilat ditampung menggunakan Erlenmeyer berisi $10 \mathrm{~mL}$ asam borat 3\% (Merck, Germany) dan beberapa tetes indikator (larutan bromcresol green 0,1\% dan 29 larutan metil merah (Sigma-Aldrich, USA) 0,1\% dalam alkohol 95\% (Univar Reagent, Singapore) secara terpisah dan dicampurkan antara $10 \mathrm{~mL}$ bromcresol green (Sigma-Aldrich, USA) dengan 2 $\mathrm{mL}$ metil merah). Tahapan ketiga adalah titrasi sebagai berikut: destilat yang dihasilkan selanjutnya dititrasi menggunakan larutan $\mathrm{HCl}$ $0,02 \mathrm{~N}$, titrasi berakhir ketika destilat berubah warnanya menjadi merah muda. Kadar protein dihitung dengan rumus:

Protein $(\%)=\frac{\left(\mathrm{V}_{A}-\mathrm{V}_{B}\right) H C l}{W \times 1000} \times N H C l \times 14,008 \times 6,25 \times 100 \%$
Keterangan: $\mathrm{V}_{\mathrm{A}}=$ jumlah larutan $\mathrm{HCl}$ titrasi contoh dalam $\mathrm{mL} ; \mathrm{V}_{\mathrm{B}}=$ jumlah larutan $\mathrm{HCl}$ untuk titrasi blangko dalam $\mathrm{mL} ; \mathrm{N}=$ normalitas $\mathrm{HCl}$ standar yang digunakan; 14,008 = berat atom Nitrogen; 6,25 = faktor konversi protein untuk ikan; $\mathrm{W}=$ berat contoh dalam $\mathrm{g}$

\section{Kadar Karbohidrat (Winarno, 1997)}

Kadar karbohidrat ditentukan menggunakan by difference dengan rumus sebagai berikut:
Karbohidrat $(\%)=100 \%$ - (kadar air + kadar abu + kadar protein + kadar lemak)

\section{Analisa Data}

Data dianalisa menggunakan rancangan acak lengkap faktor tunggal dengan tiga taraf perlakuan dan lima kali ulangan. Perlakuan yang berpengaruh nyata dilanjutkan dengan Uji Beda nyata jujur (Steel dan Torrie, 1991).

\section{HASIL DAN PEMBAHASAN}

\section{Hasil Uji Organoleptik}

Hasil uji organoleptik meliputi: aroma, rasa, dan tekstur. Tabel 1 menunjukkan hasil uji organoleptik nugget tuna ubi ungu. Hasil penelitian (Tabel 2) menunjukkan bahwa nilai organoleptik tertinggi baik nilai aroma, rasa maupun tekstur nugget ikan tuna ada pada perlakuan perbandingan ubi ungu dan tetelan tuna 10\%:90\%, yaitu masingmasing 7,6. Nilai organoleptik cenderung mengalami penurunan sebagaimana konsentrasi ubi ungu diperbesar. Hal ini menunjukkan bahwa panelis lebih menyukai nugget dengan kandungan ikan yang tinggi. 
Tabel 2. Hasil uji organoleptik nugget tuna ubi ungu

\begin{tabular}{cccc}
\hline Perbandingan & \multicolumn{3}{c}{ Uji Organoleptik } \\
\cline { 2 - 4 } $\begin{array}{c}\text { konsentrasi ubi } \\
\text { ungu : tetelan ikan } \\
\text { tuna }\end{array}$ & Aroma & Rasa & Tekstur \\
\hline $10 \%: 90 \%$ & 7,6 & 7,6 & 7,6 \\
$20 \%: 80 \%$ & 7,2 & 6,8 & 7,4 \\
$30 \%: 70 \%$ & 7 & 6,6 & 7,5 \\
\hline
\end{tabular}

Utiarahman et al. (2013), melaporkan panelis lebih menyukai aroma yang tajam, dimana aroma yang tajam diperoleh dari aroma spesifik ikan, bumbu-bumbu dan bahan tambahan. Merujuk pada standar SNI 01-6683-2002, aroma dari nugget ketiga taraf perlakuan tersebut berada pada nilai suka (nilai 7) atau mendekati nilai sangat suka (nilai 8).

Aroma merupakan bau yang sebabkan karena rangsangan kimia yang tercium oleh syarafsyaraf olfaktori pada rongga hidung. Aroma makanan dapat menentukan kelezatan dari makanan. Rasa enak makanan banyak dipengaruhi oleh aroma, aroma lebih banyak dipengaruhi oleh panca indera penciuman.

Rasa merupakan faktor yang sangat penting dalam menentukan penerimaan atau penolakan panelis terhadap bahan pangan. Rasa dapat dinilai sebagai tanggapan terhadap rangsangan bahan pangan yang memberikan kesan manis, pahit, asam, dan asin.

Penambahan bahan pengisi yang terlalu tinggi akan menutupi rasa daging, sehingga produk olahannya kurang disukai. Maka dari itu pada perlakuan perbandingan ubi ungu 30\% dan tetelan ikan tuna $70 \%$ merupakan nugget dengan bahan pengisi terbesar, sehingga nilai yang terendah atau kurang disukai daripada perlakuan lainnya. Rasa tidak hanya dipengaruhi oleh jumlah daging ikan maupun tepung yang digunakan, namun kemungkinan juga dipengaruhi rasa dari bumbubumbu yang ditambahkan, seperti dalam penelitian fish nugget memiliki rasa yang gurih spesifik yang merupakan perpaduan dari berbagai macam rasa, yakni rasa asin yang berasal dari garam, rasa pedas dari lada dan rasa manis dari gula.

Pemanasan atau penggorengan dapat menjadi penyebab timbulnya rasa pada bahan makanan. Minyak goreng yang digunakan untuk menggoreng nugget setelah proses pemasakan nugget ikan dapat menyebabkan rasa gurih pada nugget ikan. Rasa gurih dari lemak dapat menyebabkan hilangnya bau amis ketika proses penggorengan pada suhu tinggi (Erawaty, 2001).

Tekstur merupakan segi penting dari mutu makanan, kadang-kadang lebih penting daripada bau, dan rasa. Tekstur penting pada makanan lunak dan makanan renyah. Ciri yang paling penting diacu ialah kekerasan, kekohesifan dan kandungan air. Pada hasil uji organoleptik terhadap tekstur nugget tetelan ikan tuna dengan penambahan ubi ungu terdapat nilai tertinggi pada perlakuan perbandingan ubi ungu dan tetelan tuna 10\%:90\% yaitu sebesar 7,6 dan nilai yang terendah terdapat pada perlakuan perbandingan ubi ungu dan tetelan tuna 20\%:80\% yaitu sebesar 7,4. Ketiga taraf perlakuan masih berada pada nilai suka (7) atau mendekati nilai sangat suka (8).

Penggunaan tepung terigu mempengaruhi kualitas tekstur dari nugget tersebut, karena tepung terigu akan mengikat air yang terdapat dalam nugget tersebut dan membuat nugget ikan akan kenyal. Hal ini didukung oleh Widrial (2005), yang menyatakan tepung merupakan bahan pengikat yang berfungsi memperbaiki tekstur, memperbaiki cita rasa, meningkatkan daya ikat air, dan memperbaiki elastisitas produk akhir. Selain itu, tekstur juga merupakan salah satu penilaian kualitas satu produk selain dari pada nilai makanan dan $90 \%$ responden mengemukakan mutu berhubungan dengan tekstur.

\section{Hasil Analisa Proksimat}

Hasil analisa proksimat nugget tetelan ikan tuna yang disubtitusi ubi ungu, dapat dilihat pada Tabel 3 .

\section{Kadar Air}

Perlakuan perbandingan ubi ungu dan tetelan ikan tuna tidak berpengaruh nyata terhadap kadar air nugget ikan tuna. Rata-rata kadar air nugget ikan tuna pada perlakuan perbandingan konsentrasi ubi ungu: tetelan ikan tuna 10\%:90\%, 20\%:80\% dan 30\%:70\% adalah 39,414\%, $39,306 \%$ dan $39,22 \%$. Air merupakan kandungan penting dalam makanan. Air dapat berupa komponen intrasel dan ekstrasel, sebagai medium pendispersi atau pelarut dalam berbagai produk. Nugget ikan tuna hasil penenelitian ini dapat memenuhi standar mutu SNI 01-6683-2002. 
Tabel 3. Hasil uji proksimat dan uji beda nyata jujur nugget tuna dengan penambahan ubi ungu

\begin{tabular}{lccc}
\hline \multirow{2}{*}{ Uraian } & \multicolumn{2}{c}{ Perbandingan konsentrasi ubi ungu : tetelan ikan tuna } \\
\cline { 2 - 4 } & $10 \%: 90 \%$ & $20 \%: 80 \%$ & $30 \%: 70 \%$ \\
\hline Kadar Air (\%) & $39,414 \mathrm{a}$ & $39,306 \mathrm{a}$ & $39,226 \mathrm{a}$ \\
Kadar Abu (\%) & $2,148 \mathrm{a}$ & $2,002 \mathrm{~b}$ & $1,72 \mathrm{c}$ \\
Kadar Protein (\%) & $30,35 \mathrm{a}$ & $27,42 \mathrm{~b}$ & $25,238 \mathrm{c}$ \\
Kadar Lemak (\%) & $1,546 \mathrm{a}$ & $1,476 \mathrm{~b}$ & $1,378 \mathrm{c}$ \\
Kadar Karbohidrat (\%)* & 26,542 & 29,796 & 32,438 \\
\hline
\end{tabular}

Keterangan: Huruf dibelakang angka adalah hasil Uji BNJ, dimana angka yang diikuti huruf yang sama tidak berbeda pada tingkat kepercayaan $(p<0,05)$ untuk masing-masing parameter. *Untuk Kadar Karbohidrat tidak dilakukan perhitungan Analysis of Varian maupun BNJ karena jumlahnya hanya ditentukan secara by different dengan menghitung selisih dari jumlah rata-rata kadar air, kadar abu, kadar protein, dan kadar lemak.

Kadar air merupakan faktor yang sangat penting pada daya tahan suatu produk olahan. Makin rendah kadar air maka pertumbuhan mikroba makin lambat dan daya tahan produk semakin lama, dan sebaliknya semakin tinggi kadar air maka makin cepat mikroba berkembang biak dan menyebabkan proses pembusukan berlangsung lebih cepat, sebab air dalam produk bahan pangan merupakan media untuk proses enzimatis, mikrobiologi dan kimia.

Menurut Fellows (1992), kadar air bahan pangan dipengaruhi oleh proses pengolahan. Proses pengukusan dengan uap panas cenderung akan meningkatkan kadar air bahan pangan, sedangkan proses penggorengan akan menurunkan kadar air bahan pangan akibat penguapan pada bagian luar bahan pangan.

\section{Kadar Abu}

Perlakuan perbandingan ubi ungu dan tetelan ikan tuna berpengaruh sangat nyata $(P<$ $0,01)$ terhadap kadar abu nugget ikan tuna. Tabel 3. menunjukkan terjadi penurunan kadar abu sesuai meningkatnya persentasi ubi ungu dalam adonan. Rata-rata nilai kadar abu dari perlakuan perbandingan konsentrasi ubi ungu:tetelan ikan tuna 10\%:90\%, 20\%:80\% dan 30\%:70\% berturutturut adalah $2,14 \%, 2,002 \%$ dan $1,72 \%$.

$\mathrm{Abu}$ merupakan ukuran dari komponen anorganik yang ada dalam suatu bahan makanan. Kadar abu tidak selalu ekuivalen dengan bahan mineral karena ada beberapa mineral yang hilang selama pembakaran dan penguapan (Winarno, 1997).

Pengujian kadar abu terhadap produk nugget ikan tuna dilakukan pada nugget sebelum digoreng. Peningkatan kadar abu nugget ikan tuna dipengaruhi oleh kandungan daging ikan dalam komposisi adonan. Semakin banyak daging tetelan ikan tuna maka kadar abu semakin tinggi. Hal ini disebabkan karena tetelan ikan tuna kaya akan mineral yakni besi, fosfor dan lain-lain, sedangkan dari hasil kombinasi dilihat bahwa semakin banyak penggunaan ubi ungu dan tetelan maka abu yang didapatkan semakin berkurang karena kadar abu yang diperoleh berasal dari bahan baku.

Komposisi kandungan abu dalam makanan adalah merupakan hasil dari sisa pembakaran zat organik yang mengandung mineral seperti kalsium, sodium, belerang, fosfor dan bahan lainnya (Winarno, 1997), disamping itu garam dan bahan pengawet dalam bahan mentah juga berpengaruh terhadap kadar abu (Widrial, 2005). Kadar abu berasal dari zat anorganik, dimana pada proses pembakaran bahan organik terbakar, akan tetapi zat anorganik tidak.

\section{Kadar Protein}

Perlakuan perbandingan ubi ungu dan tetelan ikan tuna berpengaruh sangat nyata $(P<$ $0,01)$ terhadap kadar protein nugget ikan tuna. Semakin tinggi persentasi ubi ungu kadar protein nugget ikan tuna semakin kecil. Hasil penelitian pada Tabel 3 menunjukkan bahwa analisa rata-rata kadar protein nugget ikan tuna perlakuan perbandingan konsentrasi ubi ungu:tetelan ikan tuna 10\%:90\%, 20\%:80\% dan 30\%:70\% berturutturut adalah $30,35 \%, 27,42 \%$ dan $25,238 \%$. Hasil Uji BNJ ketiga perlakuan menunjukkan perbedaan yang nyata pada tingkat kepercayaan $(P<0,05)$, oleh karena itu perlakuan terbaik yang bernilai nutrisi terbaik adalah perlakuan perbandingan konsentrasi ubi ungu:tetelan ikan tuna 10\%:90\%. Kadar protein nugget yang dihasilkan berkisar antara 25,238\%-30,35\%. Standar mutu SN 016683-2002 tentang kadar protein nugget minimal $12 \%$ (\%bb) sehingga kadar protein pada nugget ikan tuna yang dihasilkan memenuhi syarat dalam mutu SNI. Hal ini bertolak belakang dengan hasil penelitian nugget hasil subtitusi tepung ubi jalar 
ungu oleh Ramadhani et al. 2018 dimana hasil penelitian mereka menunjukkan kadar protein berkisar antara 7,74 sampai 8,27 \%. Nurlaila et al. (2016) menyatakan bahwa penambahan konsentrasi ikan berpengaruh terhadap kadar protein nugget yang dihasilkan. Mahmud et al. (2008) menyatakan peningkatan kandungan protein nugget selain dipengaruhi bahan baku juga dipengaruhi penambahan bahan-bahan seperti kuning telur dan susu bubuk skim.

\section{Kadar Lemak}

Hasil penelitian menunjukkan perlakuan perbandingan ubi ungu dan tetelan ikan tuna sangat nyata berpengaruh $(P<0,01)$ terhadap kadar lemak nugget ikan tuna. Hasil pada Tabel 3 menunjukkan rata-rata kadar lemak nugget ikan tuna untuk perlakuan perbandingan konsentrasi ubi ungu:tetelan ikan tuna 10\%:90\%, 20\%:80\% dan $30 \%: 70 \%$ berturut-turut adalah 1,546\%, 1,467\% dan $1,378 \%$. Hasil uji BNJ menunjukkan terdapat perbedaan di antara rataan ketiga taraf perlakuan. Semakin tinggi jumlah ubi ungu yang diberikan maka semakin rendah kandungan lemak nugget ikan tuna. Kadar lemak pada produk ini telah memenuhi mutu berdasarkan SNI 01-6683-2002 yaitu maksimal $20 \%$. Kadar lemak pada nugget tetelan ikan tuna tidak terlalu tinggi karena ikan tuna jenis yellowfin memiliki kandungan lemak sebesar $0,1 \%$ dan kadar lemak ubi ungu dan tepung terigu sekitar 0,2\%. Kadar lemak pada nugget tetelan ikan tuna selain berasal dari ikan juga berasal dari kuning telur. Kandungan lemak yang tinggi dari kuning telur yaitu sekitar 32,2\% (Buckle et al., 1987), menjadi penyumbang lemak pada nugget ikan tuna. Kadar lemak dipengaruhi oleh kadar air pada nugget tetelan ikan tuna. Menurut Widrial (2005), terhadap hubungan linear antara kadar air dan kadar lemak seperti pada nugget setelah di kukus, dimana air yang terkandung pada bahan akan menguap dan minyak yang masuk akan menggantikan posisi air.

\section{Kadar Karbohidrat}

Hasil penelitian menunjukkan kadar karbohidrat rata-rata nugget ikan tuna berkisar antara 26,542-32,438\%. Kadar karbohidrat mengalami kenaikan seiring dengan meningkatnya persentasi ubi ungu dalam perbandingan antara ubi ungu dan tetelan ikan tuna (Tabel 3). Menurut standar SNI 01-6683-2002, nugget tetelan ikan telah melebihi standar yang diperbolehkan, karena batas maksimal nilai karbohidrat adalah $25 \%$. Hal ini sama dengan hasil penelitian Ramadhani et al.
(2018) dimana kandungan karbohidrat pada nugget ikan tuna dengan penambahan ubi ungu juga berada di atas nilai dari standar yang diperbolehkan oleh Badan Standarisasi Nasional (2002). Besarnya kandungan karbohidrat yang dihasilkan berasal dari bahan pengikat yang digunakan oleh pembuatan nugget tetelan ikan tuna yaitu ubi ungu dan tepung terigu. Kandungan karbohidrat pada ubi ungu sekitar 70-90\% (Meyer, 1982). Priwindo (2009) menyatakan karbohidrat berfungsi sebagai bahan pengikat bahan yang satu dengan yang lain dalam adonan, sehingga sangat diperlukan dalam pembuatan nugget untuk memperbaiki tekstur. Selain itu karbohidrat juga berperan penting dalam memperbaiki karakteristik makanan seperti aroma, rasa dan tekstur (Winarno, 1997). Ubi ungu dan tepung terigu mampu menghasilkan citra rasa yang enak, meningkatkan elastisitas produk, memperbaiki tekstur, dan meningkatkan daya ikat air sehingga produk akan lebih renyah.

\section{KESIMPULAN}

Perlakuan penambahan ubi ungu pada nugget tetelan ikan tuna mengakibatkan perbedaan mutu pada nugget yang dihasilkan. Dari hasil organoleptik dapat disimpulkan bahwa pada perlakuan perbandingan ubi ungu:tetelan ikan tuna 10\%:90\% memiliki aroma, rasa dan tekstur yang lebih tinggi atau yang terbaik dibandingkan dengan perlakuan 20\%:80\% dan 30\%:70\%. Panelis lebih menyukai nugget pada perlakuan 10\%:90\%, hal ini disebabkan oleh penggunaan tetelan ikan membuat nugget beraroma khas, rasanya gurih serta teksturnya tidak hancur ketika digigit.

Uji Proksimat menunjukkan penambahan ubi ungu pada pembuatan nugget ikan tuna berpengaruh sangat nyata terhadap kadar protein, kadar lemak dan kadar abu. Semakin besar persentasi ubi ungu pada nugget ikan tuna maka kadar protein, kadar abu semakin kecil. Namun penambahan ubi ungu tidak berpengaruh terhadap kadar air nugget tuna. Secara keseluruhan kandungan proksimat nugget ikan tuna hasil penelitian ini berada pada standar yang di anjurkan oleh SNI nugget ikan.

\section{UCAPAN TERIMA KASIH}

Ucapan terima kasih disampaikan kepada Ketua Laboratorium Teknologi Hasil Perikanan Fakultas Perikanan dan Ilmu Kelautan Universitas 
Pattimura yang telah memfasilitasi pengujian parameter dan persiapan bahan dan alat uji.

\section{DAFTAR PUSTAKA}

AOAC. 2005. Association of Official Analytical Chemistry, Official Method of Analysis. 18th Editor. Benjamin Franklin. Washington D.C.

[BSN] Badan Standarisasi Nasional. 2002. Nugget Ayam. SNI 01-6683-2002. Badan Standarisasi Nasional: Jakarta.

[BSN] Badan Standarisasi Nasional. 2006. Petunjuk Pengujian Organoleptik dan atau Sensori. SNI 01- 2346-2006. Jakarta: Badan Standarisasi Nasional.

Buckle, K.A., R.A. Edwards, G.H. Fleet, dan M. Wootton. 1987. Ilmu Pangan. Universitas Indonesia Press. Jakarta.

Departemen Kesehatan (Depkes). 1981. Daftar Komposisi Bahan Makanan. Penerbit Bharata. Jakarta.

Desmelati, dan R. Hayati. 2008. Optimasi berbagai tepung kanji pada nugget Ikan Patin terhadap karakteristik sensori dengan metode permukaan Respon. Jurnal Floratek 3: 35-49.

Erawaty, W.R. 2001. Pengaruh Bahan Pengikat, Waktu Penggorengan, dan Daya Simpan terhadap Sifat Fisik dan Organoleptik Prodak Nugget Ikan Sapu-sapu (Hyposascus pardalis). [Skripsi]. Jurusan Teknologi Hasil Perikanan. Fakultas Perikanan dan Ilmu Kelautan. Institut Pertanian Bogor. Bogor.

Fellows, P.J. 1992. Food Processing Technology, Principles and Practice. Ellis Horwood Limited, Sussex, England.

Herawati, P. 2009. Karakteristik Nugget Ikan Kurisi (Nemipterus nematophorus) Dengan Penambahan Karagenan dan Tepung Tapioka. [Skripsi]. Fakultas Teknologi Pertanian. Institut Pertanian Bogor. Bogor.

Kantun, W., A. Mallawa, dan N.L. Rapi. 2014. Struktur ukuran dan jumlah tangkapan tuna madidihang Thunnus albacares menurut waktu penangkapan dan kedalaman di Perairan Majene Selat Makassar. Jurnal Saintek Perikanan 9: 39-48. DOI: 10.14710/ijfst.9.2.39-48.

Kusumaningrum, M., Kusrahayu, dan S. Mulyani. 2013. Pengaruh berbagai filler terhadap kadar air, rendemen dan sifat organoleptik chicken nugget. Animal Agriculture Journal 2: 370-376.
Laksono, M.A., V.P., Bintoro, dan S. Mulyani S. 2012. Daya ikat air, kadar air dan protein nugget ayam yang disubsitusi dengan Jamur Tiram Putih (Pleurotus ostreatus). Animal Agriculture Journal 1: 685-696.

Maghfiroh, I. 2000. Pengaruh Penambahan Bahan Pengikat Terhadap Karakteristik Nugget Ikan Patin (Pangasius hypothalamus). [Skripsi]. Program Studi Teknologi Hasil Perikanan. Fakultas Perikanan. Institut Pertanian Bogor. Bogor.

Mahmud, M.K., Hermana, N.A. Zulfianto, I. Ngadiarti, dan R.R. Apriyantono. 2008. Tabel Komposisi Pangan Indonesia. Kompas Gramedia. Jakarta.

Meyer, L.H. 1982. Food Chemistry. The AVI Publishing Company Inc. Westport. University of California.

Nurhalimah, L., S. Fathonah, dan D. Nurani. 2012. Kandungan gizi dan daya terima makanan tambahan ibu hamil trimester pertama. Food Science and Culinary Education Journal 1: 1-12. DOI: 10.15294/fsce.v1i1.339.

Nurlaila, A. Sukainah, dan Amiruddin. 2016. Pengembangan produk sosis fungsional berbahan dasar ikan tenggiri (Scomberomorus sp.) dan tepung daun kelor (Moringa oleifera L). Jurnal Pendidikan Teknologi Pertanian 2: 105-113. DOI: 10.26858/jptp.v2i2.5165.

Priwindo, S. 2009. Pengaruh Pemberian Tepung Susu sebagai Bahan pengikat terhadap Kualitas Nugget Angsa. [Skripsi]. Fakultas Pertanian, Universitas Sumatera Utara. Medan.

Ramadhani, D.T., Ansharullah, dan K.T. Isamu. 2018. Pengaruh substitusi tepung ubi jalar ungu (Ipomoea batatas L.) terhadap penilaian organoleptik, nilai gizi dan aktivitas antioksidan nugget ikan Tuna (Thunnus sp). Journal Sains dan Teknologi Pangan 3: 1448-1459.

Restu. 2012. Pemanfaatan ikan Toman (Channa micropeltes) sebagai bahan nugget. Jurnal Ilmu Hewani Tropika 1: 17-38.

Rosyidi, D., A.S. Widati, dan J. Prakoso. 2008. Pengaruh penggunaan rumput laut terhadap kualitas fisik dan organoleptik chicken nugget. Jurnal Ilmu dan Teknologi Hasil Ternak 3: 43-51.

Saniah, K. and Z.C. Rahani. 2011. Acceptability and textural quality of Sri Pontian cassava nuggets using Response Surface 
Methodology. Journal Tropical Agricultural and Food Science 39: 131-139.

Soekarto. 1990. Penilaian Organoleptik Untuk Industri Pangan dan Hasil Pertanian. Bhatara Aksara. Jakarta.

Steel, R.G.D. dan J.H. Torrie. 1991. Prinsip dan Prosedur Statistika: Suatu Pendekatan Biometrik. Diterjemahkan oleh Bambang Sumantri. PT. Gramedia Pustaka Utama. Jakarta.

Utiarahman, G., R.M. Harmain, dan N. Yusuf. 2013. Karakteristik kimia dan organoleptik nugget Ikan Layang (Decapterus sp.) yang disubtitusi dengan tepung Ubi Jalar Putih (Ipomea batatas L.). Nikè: Jurnal Ilmiah Perikanan dan Kelautan 1: 126-138.

Widrial, R. 2005. Pengaruh Penambahan Konsentrasi Tepung Terigu Terhadap Mutu
Terakreditasi RISTEKDIKTI Peringkat SINTA 4, SK. 30/E/KPT/2019

Nugget Ikan Patin (Pangasius

hypophthalmus). [Skripsi]. Fakultas

Perikanan dan Ilmu Kelautan. Universitas

Bung Hatta. Padang.

Winarno, F.G. 1997. Pangan, Gizi, Teknologi dan Konsumen. PT. Gramedia Pustaka Utama. Jakarta.

Yusop, S.M., M.Y. Maskat, W.A. Mustapha, and A. Abdullah. 2009. Properties of coating systems during the initial period of deep-fat frying as affected by flour type, temperature and pressure. Sains Malaysiana 38: 177-183.

Zuraida, N. dan Y. Supriati. 2001. Usahatani ubi jalar sebagai bahan pangan alternatif dan diversifikasi sumber karbohidrat. Buletin AgroBio 4: 13-23. 